\title{
高圧蒸気タービンの不安定振動に関する研究* (部分送入の影響)
}

\author{
神吉 博*1, 谷 辻 啓 則*2
Study on Stability of High Pressure Turbine (Effect of Partial Admission)

\author{
Hiroshi $\mathrm{KANKI}^{* 3}$ and Akinori TANITSUJI \\ ${ }^{* 3}$ Department of Mechanical Engineering, Kobe University, \\ 1-1 Rokkodai-cho, Nada-ku, Kobe-shi, Hyogo, 675-8501 Japan
}

\begin{abstract}
Subsynchronous vibration of high-pressure steam turbine is one of the difficult problems to improve the reliability of power plant. Extensive work has been done to prevent the low frequency vibration of high-capacity steam turbine and most of the problems were practically solved ${ }^{(1)}$. In the future, we must build up theoretical approach to design a new turbine operating under the steam condition of high-temperature and high-pressure. To design such an advanced steam turbine, it is necessary to solve the effect of partial admission on control stage of the steam turbine. This paper describes the experimental results from the scale model of the steam turbine and theoretical analysis of destabilizing forces. In theoretical analysis, destabilizing forces that take partial admission into consideration were analyzed. As a result, it was clarified that large destabilizing force was generated in partial admission condition and the destabilizing force varied periodically by the instant rotor position. In experimental study, we designed the new inlet seal for the prevention against the vibration. From the experimental result that increase of total flow rate leads the system stable, we showed the effectiveness of new inlet seal. And we paid attention to the step-up that is the step between blade and nozzle. As a result, it was experimentally proved that the step-up had a large influence on the rotor stability.
\end{abstract}

Key Words : Vibration of Rotating Body, Damping, Self-Excited Vibration, Subsynchronous Vibration, Steam Turbine, Steam Whirl, Partial Admission, Labyrinth Seal, Step-up

\section{1. 精 晋}

近年, 温暖化現象をはじめとする環境問題に対して, 火力, 原子力, コンバインドサイクルプラントにおい て蒸気タービンの効率を高めることが必要となって いる. タービンの効率を高める方法の一つとして, 蒸 気の入口条件をさらに高温・高圧なものとする傾向に ある. これにともない, タービンの調速段において負 荷の増加に対応して発生する低周波域での振動が問 題となってきた. 蒸気タービンで発生する低周波振動 を図 1 に示す.

これらの振動は, 低次の固有振動数成分の振動であ ることが特徴である. この中で, 蒸気タービンにおけ る不安定振動はスチームホワールであり, スチームホ

* 原稿受付 2006 年 3 月 20 日.

*1 正員, 神戸大学工学部（亚675-8501 神戸市灘区六甲台町 11).

*2 学生員, 神戸大学自然科学研究科.

E-mail : kanki@ mech.kobe-u.ac.jp

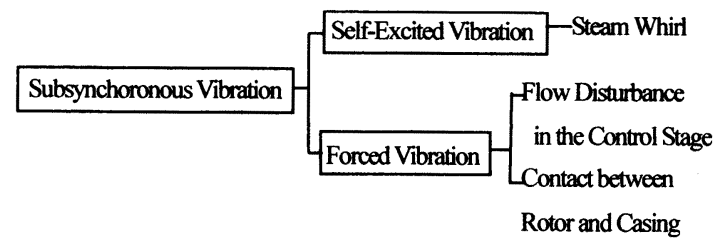

Fig.1 Classification of subsynchoronous vibration

ワールの原因としては, トルク励振力と, シール励振 力の二つの不安定化力がある.これら二つの不安定化 力が, ロータシステムの减衰を减少させ不安定振動を 引き起こしていると考えられる.

これらの不安定化力は, 全周送入時に関しては現在 までさまざまな研究がなされてきて理論的・実験的に 原因の解明がある程度の精度でなされてきている.し 
かし,ブレード翼列の一部にのみ蒸気を導入する調速 段ノズルにおける部分送入時に関しては, 全周送入時 よりも安定性が低下することがあるにもかかわらず， 部分送入がスチームホワールにあたえる影響が理論 的に十分解明されてはいないのが現状である.

スチームホワールの対策として, スクイズフィルム ダンパの設置やスワールブレーカーの設置は, 低周波 振動の対策として大きな効果を発揮している. 部分送

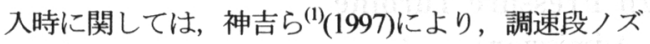
ルのバルブ開閉順序を調節することで低周波振動が 十分に低減できるという結果が実機試験によって得 られている. しかし，理論的にまだ不明な点も多い.

本論文では, スチームホワールのメカニズム解明の ため簡略化した理論を用いてトルク励振力とシール 励振力の解析と, 不安定化する采に対して安定化対策 として, 不安定化力の大きさが変化するようなラビリ ンスシールの形状, ブレード入口部分の形状を提案し, 減衰比を実験的に求めることでその有効性を確かめ た.

\section{2. 記号の定義}

$C_{r}$ : 初期クリアランス

$c:$ チャンバ内の周方向流速

$f:$ チャンバ断面積

$F:$ ロータに加わる全接線力

$F_{T F}$ : 全周送入時接線力増加分ベクトル

$F_{T P}$ : 部分送入時接線力増加分ベクトル

$L_{f}:$ 壁面での摩擦仕事

$L_{l}:$ 渦流れへの供給エネルギー

$L_{t}:$ タービン動翼長さ

$P:$ チャンバ内圧力

$q:$ 軸方向流量

$U_{r}$ : せん断応力作用面のぬれぶち長さ(ロー夕側)

$U_{s}$ : せん断応力作用面のぬれぶち長さ(ステータ

側)

$V_{a x}:$ 軸方向流速

$\beta$ : 熱力学的効率に依存する無次元数

$\varepsilon:$ ふれまわり量

$\eta_{s p}$ : ロータが偏心することにより生じる損失

$\eta_{T p}:$ 部分送入より生じる損失

$\theta:$ 瞬時のロータのふれまわりの方向 $\rho:$ 密度

$\tau_{r}:$ ロー夕表面の周方向せん断応力

$\tau_{s}$ : ステータ表面の周方向せん断応力

$\varphi$ : 偏心方向と接線力増加分ベクトルの位相差

添字

$※$ : 定常成分

$i:$ シールチャンバ番号

\section{3. 部分送入とは}

本研究の対象は調速段である. 図 2 は火力タービン であるが, 図中の丸印で示した高圧タービンの第一段 目が調速段である. 調速段の軸方向からの断面を図 3 に示す.この図は本実験装置の調速段であり, 部分送 入の方法を示している.

部分送入とは, 調速段のノズル翼列の一部にのみ蒸 気を導入することである. 部分送入を行うことで効率 を低下させずに出力を調整できる.
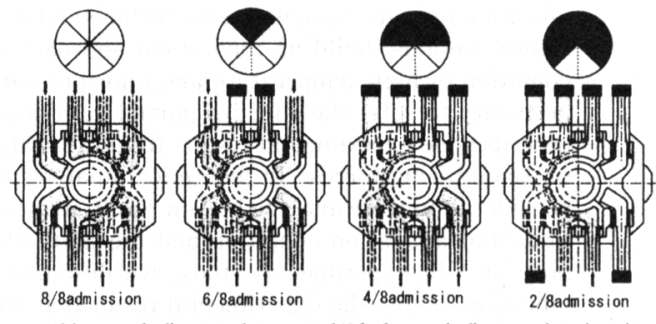

White zone indicates valve opened, Black zone indicates valve closed. Fig3 Partial admission arc patterms on the control stage of the steam turbine

\section{4. 部分送入を考慮に入れた不安定化力の理詥解析}

4-1 トルク励振力 トルク励振力は, ブレード 先端の蒸気の漏孔流量の変化によるアンバランスト ルクによって発生する. 全周送入の条件下における トルク励振力は, 一般的に次式であらわされる.

$$
K_{T}=\frac{F \beta}{2 L_{t}}
$$

このときのロータに働く接線力の $\mathrm{x}$ 方向, $\mathrm{y}$ 方向成 分は次のようにあらわされる. 計算にあたり, ロータ の静止采および回転系の座標を図 4 のように設定し た.

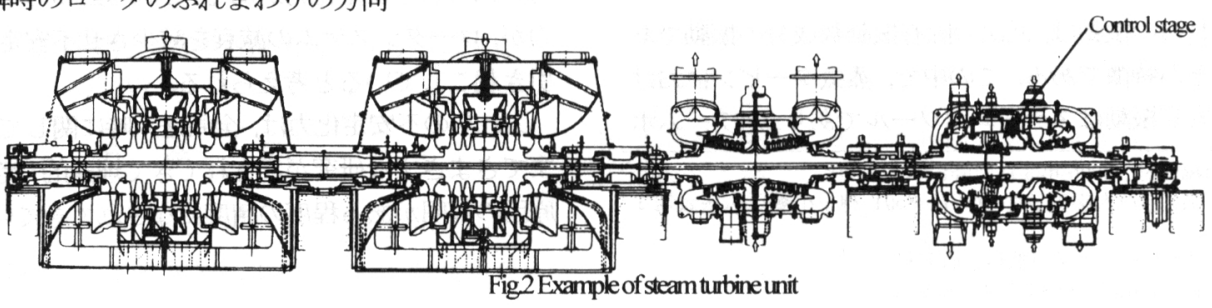


$F_{T F x}^{\prime}=-\frac{F}{2 \pi} \int_{b}^{2 \pi}\left\{\eta_{u}-\frac{\beta}{L_{t}}\left(C_{r}-\varepsilon \cos (\theta-\varphi)\right)\right\} \sin \varphi d \varphi$ (2)

$F_{T F y}^{\prime}=-\frac{F}{2 \pi} \coprod^{2 \pi}\left\{\eta_{u}-\frac{\beta}{L_{t}}\left(C_{r}-\varepsilon \cos (\theta-\varphi)\right)\right\} \cos \varphi d \varphi$ (3)

部分送入の条件下での解析にあたって, 部分送入時の 流九は, 非常に複雑な流れとなるので図 5 のように領

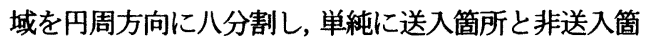
所に分けた.

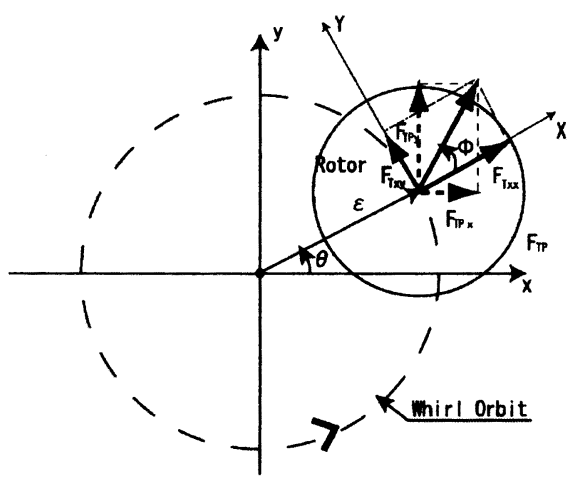

Fig 4Coordinate of stage excitaion forceanalysis

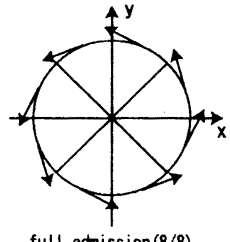

full admission (8/8)

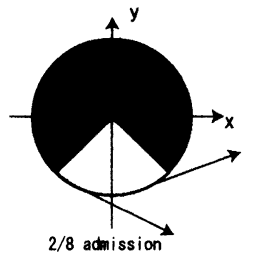

$2 / 8$ admission
Fig5 Simplification

Linhardit et al. (1961) (П)の文献で述べられている部分 送入により生じる損失 $\eta_{7 p}$ を用いて式(2), (3)を書き換 えると次のようになる。

$$
\begin{aligned}
& F_{T P X}^{\prime}=-\frac{4 F}{\sum_{k=1}^{8} a_{k}} \sum_{k=1}^{8}\left[a_{k} \int_{k-1) \pi / 4}^{k \pi / 4}\left\{\eta_{T P}-\frac{\beta}{L_{t}} \delta(\theta)\right\} \sin \varphi d \varphi\right] \\
& F_{T P y}^{\prime}=\frac{4 F^{\prime}}{\sum_{k=1}^{8} a_{k}} \sum_{k=1}^{8}\left[a_{k} \int_{k-1) \pi / 4}^{k \pi / 4}\left\{\eta_{T P}-\frac{\beta}{L_{t}} \delta(\theta)\right\} \cos \varphi d \varphi\right]
\end{aligned}
$$

また，無次元数 $\alpha_{k}$ は次のように定義されている.

$$
a_{k}= \begin{cases}1 & \text { (流体の送入あり }) \\ 0 & \text { (流体の送入なし) }\end{cases}
$$

$\mathrm{x}, \mathrm{y}$ 方向成分の增加量 $F_{T P x}, F_{T P y}$ は，偏心したと きの接線力から初期の状態(偏心のない状態)での接 線力を引いたものである.この接線力の増加量 $F_{T P}$ の ロータの偏心方向と直角の成分がトルク励振ばね定 数（連成ばね定数）である.

計算結果を図 6, 図7に示す. 図6より, トルク励振 力は瞬のロータの位置 (ふれまわり方向)によって変動 していることが氻る. 変動量は送入部分を减少させること で大きくなり，28送入時は他に比へて大きな最大值をとっ ている.これは送入部分を堿らすことでノズルから出る空気 の流速力゙大きくなり，トルク厉振力の最大值も大きくなって いると考えられる.この結果はトルク励振力がロータのブレ 一ドとケーシンク間のクリアランスに大きく依存している ことを示している. 図7は総流量の増加こ対するトルク厉振 ばれ定数の関係をあらわしている. 図よりトルク厉振力は, 総流量の増加とともに増加していき不安定化の傾向力漒く なっていくことがかかる. またその㒋向は，送入部分を减少 させるにしたがって強くなっている.

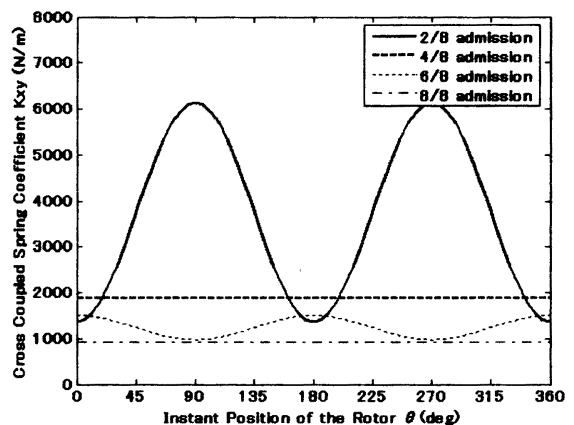

Fig6 Cross coupled spring coefficient perturbation versus instant direction of the ror $\left(0.15 \mathrm{~m}^{3} / \mathrm{s}\right)$

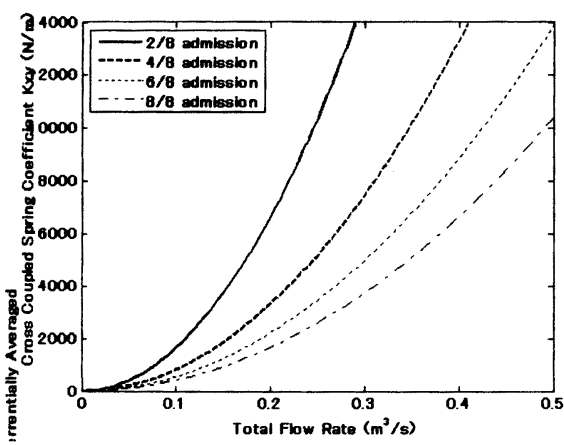

Fig 7 Cross coupled spring coefficient versus total flow rate 
4.2 シール祅振力 シール励振力とは, シールチャン 为の不均一な厓力分布か源因の不安定化力である. ジル 厉振力の計算は文献(4)に記されている方法て行ったシール 励振力の導出に際して次のような仮定をおいた。

•作動流体は気体とし理想気体の状態方程式が適用で きる

・シール内では, 温度が一定であるとする

・シール内では，等エントロピ変化をおこなう

・シールチャンバの断面積はふれまわりにより一定で なくなるが, その変化は微小であるため周方向微分を 考えず時間微分のみを考える

・部分送入時のシール内の流れは, 送入箅所と非送入 箇所間の流体の出入りはないものとする
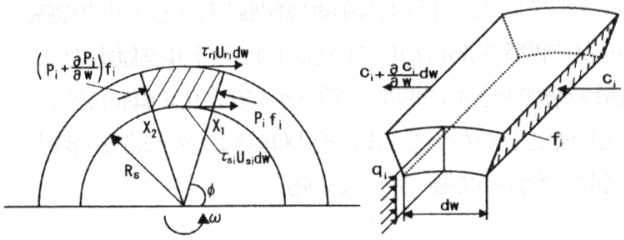

Fig.8Control volume for calculation

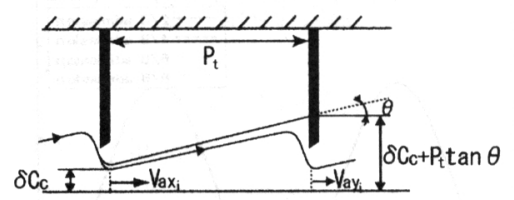

Fig9Flow pattem in the seal chamber

基礎式としては連続の式（式（6）），運動量保存 の式 (式 (7))，エネルギ一保存の式 (式 (8)) 次 の3式を用いた.

$$
\begin{gathered}
\frac{\partial\left(\rho_{i} f_{i}\right)}{\partial t}+f_{i} \frac{\partial\left(\rho_{i} c_{i}\right)}{\partial \omega}+q_{i+1}-q_{i}=0 \\
q_{i} c_{i-1}-q_{i+1} c_{i}-f_{i} \frac{\partial\left(\rho_{i} c_{i}^{2}\right)}{\partial \omega}-\frac{\partial\left(\rho_{i} f_{i} c_{i}\right)}{\partial t} \\
-\frac{\partial P_{i}}{\partial \omega} f_{i}+\tau_{s i} U_{s i}+\tau_{r i} U_{r i}=0 \\
q_{i} \frac{V_{a x i}^{2}}{2}-q_{i+1} \frac{\left(A_{i} V_{a x i}\right)^{2}}{2}-L_{f i}-L_{l i}=0
\end{gathered}
$$

これまでに得られた式の中でシールチャンバ内圧 力, 周方向流速, 軸方向流量, シールクリアランスを 定常成分と周方向の微小変動成分に分割することで 線形化をおこなう，各量を次のようにあらわす。

$$
\left\{\begin{aligned}
P_{i} & =P_{*_{i}}\left(1+\xi_{i}\right) \\
c_{i} & =c_{*_{i}}\left(1+\eta_{i}\right) \\
q_{i} & =q_{*_{i}}\left(1+\zeta_{i}\right) \\
\delta_{i} & =\delta_{*_{i}}\left(1+\psi_{i}\right)
\end{aligned}\right.
$$

式(9)を式(6)(7)(8)に代入することによってシールチ ヤンバ内圧力を計算寸ることができ, 円周方向に数值 積分することによりロータに加わる力を求めること ができる.

部分送入の状態は, 図 5 に示したように単純に領域 を送入箇所と非送入箇所に分割するとともに，図 10 のように入ロスワール流速に分布を与えることで表 現した. 本実験でのシール部の入ロスワール流速の測 定結果より, 非送入箇所での速度をほぼ 0 としている また，実機での実績よりスワールが回転方向に約 20 度ずれるという事実を考慮し, 本解析でも回転方向に 20 度ずらして速度分布を与えている.

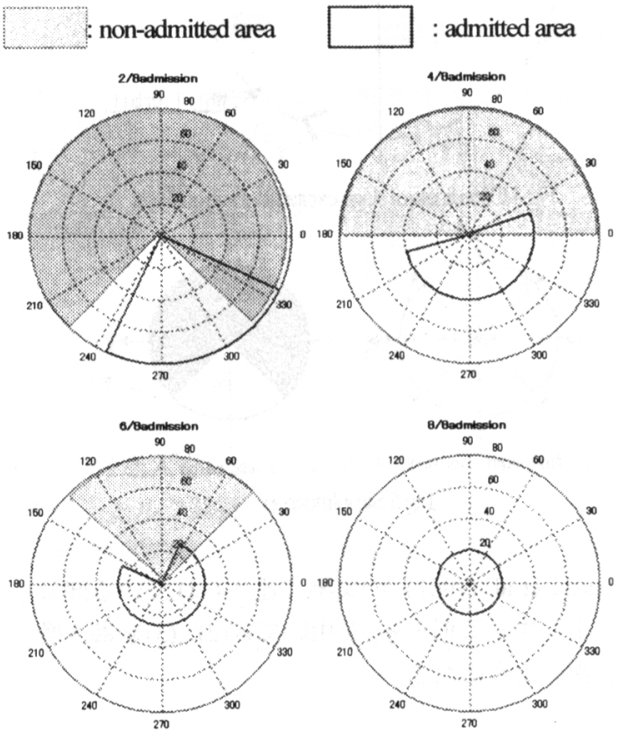

Fig.10 Distribution of inlet swirl

計算は, 図 11 に示すような本研究の実験装置 のシール部分の形状を簡略化したモデルで行っ た．また，表 1 にシール幾何を示す。

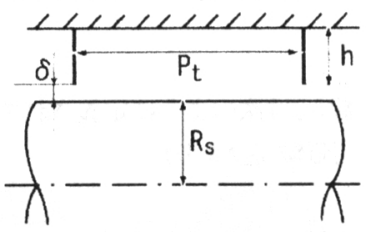

Fig.11 Seal model for analysis 
Table 1 Specification of the seal

\begin{tabular}{|c|c|}
\hline Rotor radius $R_{S}$ & $196.6 \times 10^{-3}[\mathrm{~m}]$ \\
\hline Pitch of seal $P_{t}$ & $29.4 \times 10^{-3}[\mathrm{~m}]$ \\
\hline Height of seal fin $h$ & $3.5 \times 10^{-3}[\mathrm{~m}]$ \\
\hline Clearance of $1^{\text {st }}$ seal $\delta_{I}$ & $0.8 \times 10^{-3}[\mathrm{~m}]$ \\
\hline Clearance of $2^{\text {nd }}$ seal $\delta_{2}$ & $0.8 \times 10^{-3}[\mathrm{~m}]$ \\
\hline Wetted perimeter length $U_{s}$ & $34.4 \times 10^{-3}[\mathrm{~m}]$ \\
\hline Wetted perimeter length $U_{r}$ & $29.4 \times 10^{-3}[\mathrm{~m}]$ \\
\hline
\end{tabular}

計算結果を図 12, 図 13 に示す。

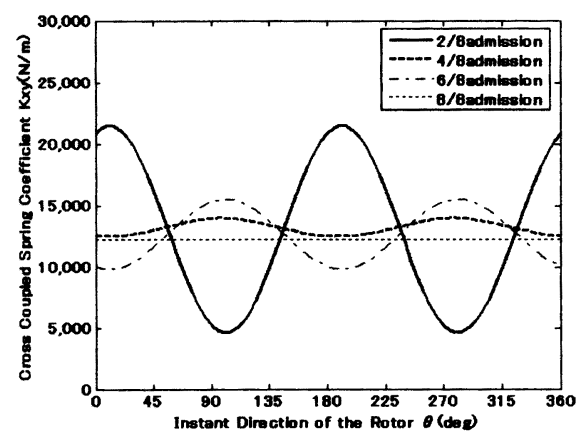

Fig.12 Cross coupled spring coefficient perturbation versus instant direction of the rotor

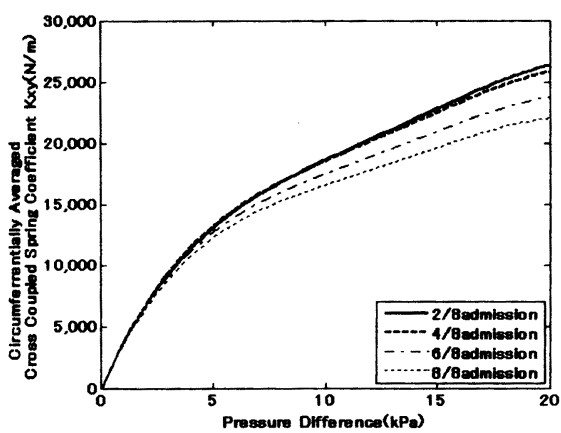

Fig13 Cross coupled spring coefficient versus pressure difference

図 12 の瞬時のロータの位置（ふれまわり方向）と シール励振ばね定数の関係のグラフより, 部分送入に おいてロータの位置によってシール励振ばね定数の 值が周期的に変化していることがわかる. その周期的 変化の振幅は $2 / 8$ 送入において特に大きい, 不安定化 力の円周方向の平均値に関しては部分送入間の違い は僅かであったが，2/8送入などの部分送入において は, ロータの位置によって局所的にシール励振ばね定 数が非常に大きくなることがあるということがわか
る. $4 / 8$ 送入と $6 / 8$ 送入を比べると $6 / 8$ 送入のほうが周 期的変化の振幅が大きいが, これはノズルの開き方が 6/8 送入では対称になっていないためであると考えら れる. 8/8 送入 (全周送入) においてはロータの位置 によるばね定数の変化は見られなかった. 図 13 より, シール前後の圧力差を増加させるとシール励振ばね 定数の值が增加することがわかる. 各部分送入間の差 は, 圧力差を增加させるにしたがって大きくなり, 2/8 送入において最も不安定化力が大きくなっている.

\section{5. 实}

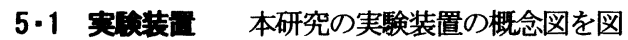
14 に, 写真を図 15 に示す. また, ロータ系の諸元を 表 2 に示す．実験装置の特徴は以下のとおりである.

1）蒸気タービンの調速段をモデルとした実験装置で ある

2）作動流体として空気を用いている

3）ブロワで吸引することで赛験装置内に空気を流す

4）インバータを用いることによりブロワの回転数を 変化させ空気の総流量を変化させることができる

5）非接触変位センサにより軸の振動を測定する

6）不安定振動が発生しやすいように, 系全体の减衰 比、固有振動数は低く設計されている

7）空気の送入口は 8 個あり，ふたを開閉することで 部分送入を行うことができる

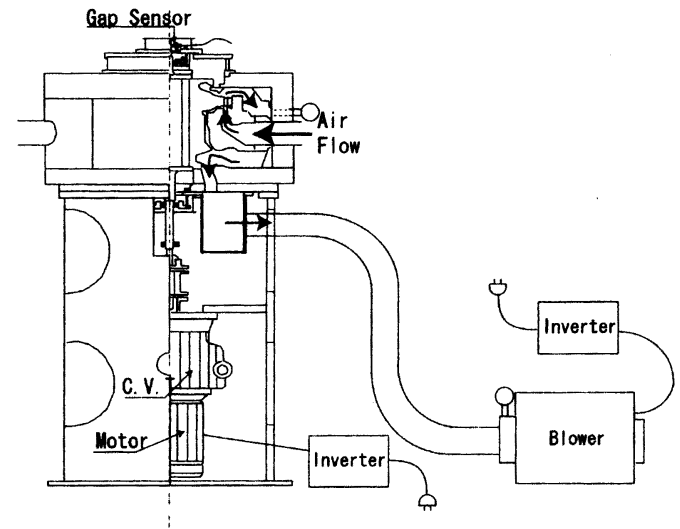

Fig.14 Schemetic of experimental apparatus 


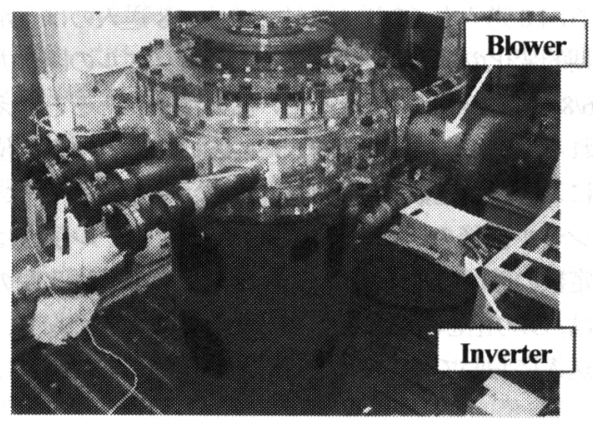

Fig,15 Picture of experimental apparatus

Table 2 Specification of the rotor system

\begin{tabular}{|l|l|}
\hline Tipseal clearance & $0.8 \mathrm{~mm}$ \\
\hline Rotor diameter & $376.6 \mathrm{~mm}$ \\
\hline Rotor mass & $47 \mathrm{~kg}$ \\
\hline Rotor speed & $0.5 \mathrm{~Hz}$ \\
\hline Height of seal fin & $3.5 \mathrm{~mm}$ \\
\hline Pitch of seal fin & $30.5 \mathrm{~mm}$ \\
\hline Height of turbine blade & $11.6 \mathrm{~mm}$ \\
\hline Number of turbine blade & 112 \\
\hline Maximum total flow rate & $0.5 \mathrm{~m}^{3} / \mathrm{s}$ \\
\hline Maximum vaaum pressure & $20 \mathrm{kPa}$ \\
\hline
\end{tabular}

\section{$5 \cdot 2$ 実験を行ったシールタイプ(ブレード入口形} 状）今回実験を行ったシールタイプを図 16, 図 17, 図 19 に示寸。それぞれの特徴を以下に示寸.

基準タイプ（Type1） 安定化対策などを施してい ないタイプ.

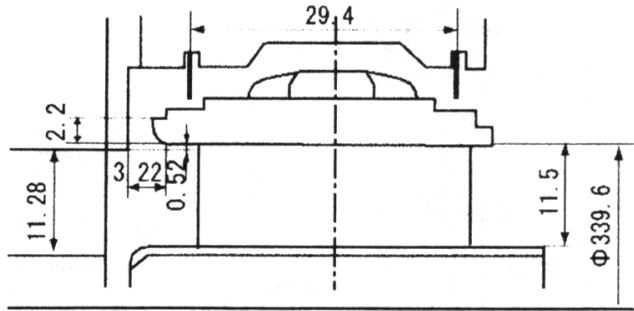

Fig 16 Geometry ofblade entrance for standard case

逆絞りフィンタイプ（Type2）安定化対策として シール人口部分に今回新しく設計した逆絞りフィン を取り付けたもの. 逆絞りフィンの効果は, ロータの ふれまわり運動によって生じる隙間（図 17 の○印で 示した部分）の変化を全く反対にすることができる. つまり, ロータの偏心方向の隙閒が大きくなり，偏心
方向と反対側の隙間が小さくなる. (図 18 参照) そ の結果, 逆絞りフィンを取り付けることでトルク励振 力の正負の符号が逆転し, 安定化力が生み出されるこ とになる.

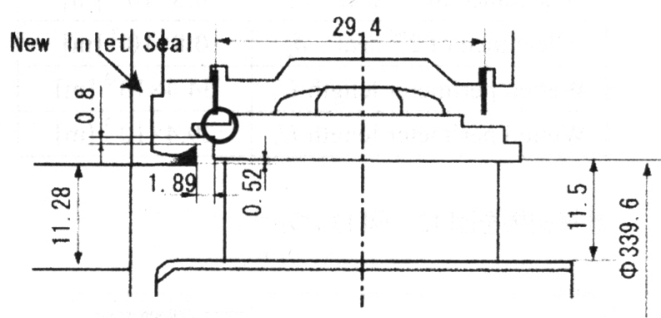

Fig17 Geometry of bladeentrance fornew inlet seal case

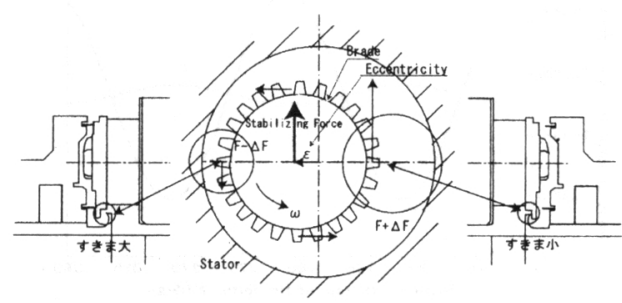

Fig18Effect of newinletseal

ステップアップタイプ (Type3) ステップアップ を Type1 より大きくしたもの. (Type $1=0.52 \mathrm{~mm}$, Type3=2.52mm） ステップアップとは, 図 19 に示す, ズル出口と動翼入口部分の段差 $h$ のことであり,この ノズル出口からの流れの広がりを効率よくブレード で吸収するために設けられている.このステップアッ プ量の大きさがブレードの効率だけでなく, ロータの 安定性に影響を与えるという観点から, 初めて研究を 行ったのは旧ソ連である. (6)ここでは, ステップアッ プの大きさによりロータ系の安定性が変化することが述べ られている. 本実験装置のブレード入口寸法を用いて文献(6) で計算すると, Typel では不安定化の領域こあるのに対して, Type3 では安定化の領或こあることがわからた

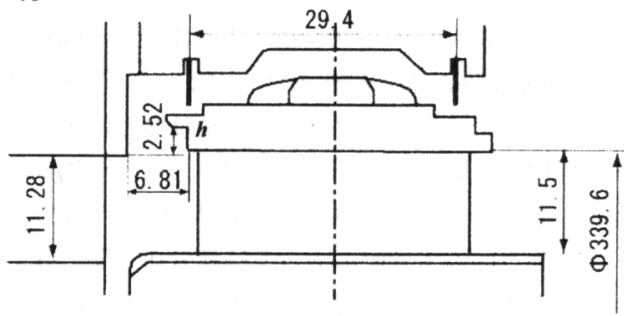

Fig19Geometry ofblade entrance forstep-up case 
5.3 実験結果 先に示した三つのシールタイプ について安定性を確かめるために流量 (負荷) と減衰 比の関係を実験によって求めた. 減衰比は减衰自由振 動波形功求めた。 結果を以下に示寸.

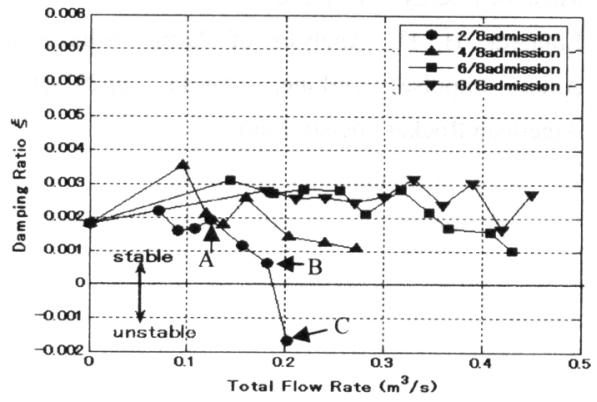

Fig.20 Measured damping ratio for standard case

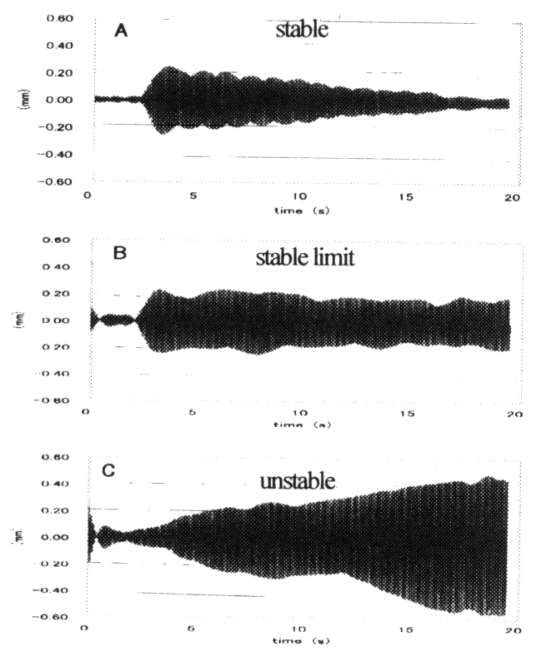

Fig.21 Time waves showing the amplitude of vibration at the points A $\mathrm{B}$ and $\mathrm{C}$ on the figure 20

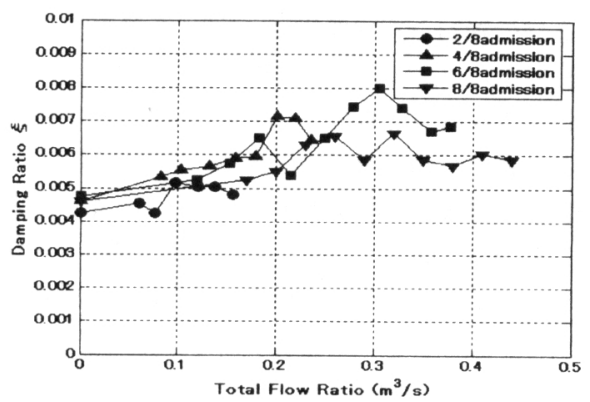

Fig.22 Measured damping ratio for new inlet seal case

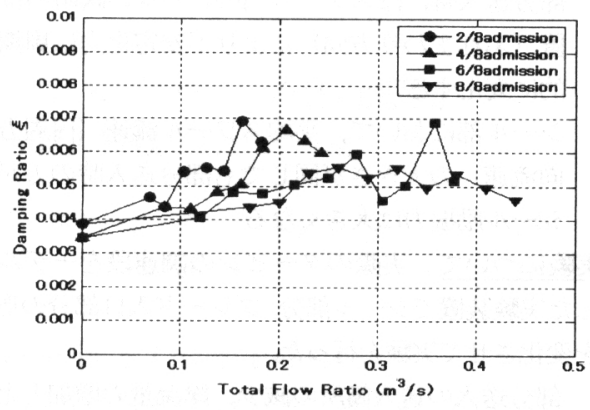

Fig.23 Measured damping ratio for step-up case

図 20 は基準タイプのシールでの実験結果を示して いる. グラフより総流量の増加, 部分送入の送入䇢所 の減少に従って减衰比が低下しロー夕系の安定性が 低下していることがわかる。 また， $2 / 8$ 送入において 不安定振動を発生させることができた. 図 21 は図 20 中の $2 / 8$ 送入の各条件 $(\mathrm{A}, \mathrm{B}, \mathrm{C})$ における時閒波形を示 している. グラフより流量の増加に従って安定性が低 下している様子が確認できる.

図 22 は逆絞りフィンを取り付けたときの実験結果 である. 実験の結果, 総流量が増加しても隇衰比が低 下せず, 反対に増加した，また，部分送入の送入箇所 を減少させても系が不安定化しなかった. ロータ系は 逆絞りフィンによって安定化力 (マイナスのトルク励 振力）が働き安定化していることから，この実験結果 より逆絞りフィンの有効性が確認できた.

図 23 はステップアップ量を増加させて実験を行っ た結果である.この実験結果でも滅衰比は低下するこ となく増加していることから安定性は増加している と考えられる.つまり,ここではステップアップの増 加により安定化力が生じることが初めて確認できた.

トルク励振力の発生原因を詳しく分けると, シール リークによるトルク励振力とステップアップによる トルク励振力の二種類に分けられる. 逆絞りフィンは この中でシールリークによるトルク励振力の符号を 負にすることで安定化力を発生させた. また, ステッ プアップの増加はステップアップによるトルク励振 力を安定化力として働かせることになった。

\section{6. 結 言}

以下のことを結言とする.

理論について 部分送入を考虑に入れたトルク励 振力とシール励振力の単純化した理論解析を行った.

1) 部分送入の送入籄所の減少, 総流量 (負荷) の 増加とともに不安定化力が大きくなる 
2）部分送入時にはステータ内のロータの瞬時の位 置（ふれまわり方向）により不安定化力は周期 的に変化する

3）シール部において, 平均スワール流速（円周方 向流速）の大きさが同じでも部分送入時の方が シール励振力は大きくなる

実䀦について 実際のタービンの調速段をモデル とした実験装置でシール部分, ブレード入口部分の形 状を変化させて実験を行った.

4) 部分送入の送入箇所の減少, 総流量の増加とと もに减衰比が減少しロータ系の安定性が低下寸 るという理論と一致する結果が得られた

5）モデル奏験では不可能とされてきた不安定振動 発生を独特の工夫により解決し, 実際に不安定 振動を低い圧力で発生させることができた

6) 振動対策として逆絞りフィンを新しく設計し実 験して, 流量 (負荷) が増加しても減衰比が低 下せずに上昇する結果が得られ逆絞りフィンの 有効性が確認できた

7）ステップアップがロータの安定性に大きな影響 を与えることをはじめて実験により実証した

\section{辞}

長年の研究支援に対し三菱重工業（株）の関係者の 皆様に深く感謝します.

(1) Kanki, H. et al.., PREVENTION OF LOW-FREQUENCY VIBRATION OF HIGH-CAPACITY STEAM TURBINE UNITS BY SQUEEZE-FILM DAMPER, Transaction of the ASME DETC'97 (1997)

(2) Kanki, H. and Tanitsuji A., STABILITY OF HIGH PRESSURE TURBINE UNDER PARTIAL ADMISSION CONDITION, ASME paper DETC2005-84774, 2005

(3) Ehrich., F, F., HANDBOOK OF ROTERDYNAMICS, McGraw Hill, Inc (1992)

(4) Iwatsubo, T. et al., The Unstable Vibration of the Rotor with Labyrinth Seals : 3rd Report, The Fluid Force Based on the Theory Considering Energy Loss in Labyrinth Seals, Journal of the Japan Society of Mechanical Engineers, Vol. 51, No. 462 (1985), pp. 288-296.

(5) Komotori, K., A Consideration on the Labyrinth Packing of Straight Through Type, Journal of the
Japan Society of Mechanical Engineers, Vol. 23, No. 113 (1957), pp. 617-623.

(6) B, T, RUNOF.(in Russia), Research and Prevention for Vibration of Steam Turbine Unit, (1982), pp.315, Moscow Energy Publishing

(7) Linhardt, H, D., Analysis of Partial Admission Axial Impulse Turbine, (1961), pp297-308, American Rocket Society Journal 